\title{
Why do they return? Beyond the economic drivers of graduate return migration
}

\author{
Riccardo Crescenzi ${ }^{1}$ - Nancy Holman ${ }^{1}$. \\ Enrico Orru'1
}

Received: 1 May 2015 / Accepted: 24 March 2016 / Published online: 19 April 2016 (C) The Author(s) 2016. This article is published with open access at Springerlink.com

\begin{abstract}
This paper explores the factors that shape the location choices of formerly mobile graduates (FMGs) initially resident in Sardinia, Italy, a less developed European region. Combining qualitative and quantitative techniques, the paper examines the reasons why some individuals decide to return after their studies, the factors that shape their decisions and how these choices unfolded in space and time. It counters the literature, which suggests that migration is a one-off linear process driven only by wealth-maximising behaviour, positing rather that access to opportunities in open meritocratic job markets and circular migration trajectories are far more salient to FMGs. This suggests that policy makers should concentrate on promoting labour market opportunities and invest in social networks that will aid brain circulation.
\end{abstract}

JEL Classification J24 $\cdot \mathrm{J} 61 \cdot \mathrm{R} 23 \cdot \mathrm{R} 58$

\section{Introduction}

There has been a long-held belief in European policy circles that funding student mobility (SM) will bring about positive net benefits to Europe, its nation states and

Electronic supplementary material The online version of this article (doi:10.1007/s00168-016-0762-9) contains supplementary material, which is available to authorized users.

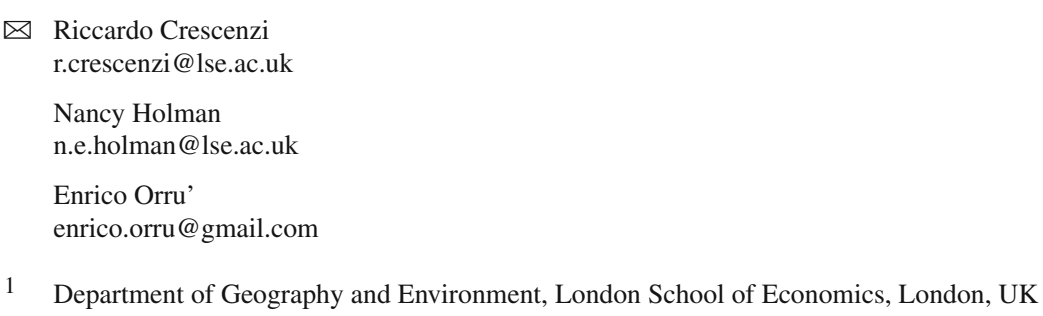


regions and ultimately to individuals. Countless schemes have been launched promising to enhance the human capital and employability of funding recipients, to increase knowledge flows between economic systems and even to boost an overall sense of European citizenship. However, and this is especially true for less developed regions, SM can lead to a number of unwanted negative effects. One of the most widely discussed is 'brain drain' i.e. the asymmetric migratory flows of skilled individuals from areas where economic conditions are worse (less developed regions) to locations where they are better (core regions).

The potential risk of brain drain associated with SM has been acknowledged by both scholars (King and Ruiz-Gelices 2003; Oosterbeek and Webbink 2011; Parey and Waldinger 2011) and policy makers (European Commission 2002). As a result, a number of schemes have been designed in order to mitigate brain drain problems by means of incentives paid to returners (or to employers in their home regions) relying on the assumption that locational choices are made according to economic utility. However, academic studies pertaining to brain circulation and SM are still in their infancy and do not yet provide a clear and conclusive explanation of what fosters return migration of formerly mobile graduates (FMG) (Milio et al. 2012; Thorn and Holm-nielsen 2008).

This paper aims to contribute to these debates by exploring the factors that shape the location choices of formerly mobile graduates. The paper addresses a number of fundamental research questions: What factors shape the location decisions of FMG? What drives some of them to return to less developed regions? How are these choices unfolded in space and time?

In order to answer these research questions, the paper looks-with a combination of quantitative and qualitative methods - at a unique dataset of individuals who were previously recipients of a large SM grant scheme launched by the Italian region Sardinia and funded by the European Social Fund (ESF). The former beneficiaries of this programme — called Master and Back Higher Education (M\&B)—form a homogenous large sample of individuals who-at the time of application-were residents in a less developed European region and received a scholarship to study for a Master or a $\mathrm{PhD}$ programme in another Italian region or abroad.

The analysis of this unique sample makes it possible to study the location behaviour of previously mobile individuals following the completion of their postgraduate studies. In so doing, the paper aims to shed new light on the attitudes and behaviours of a (self-)selected group of highly skilled mobility-prone (given their participation in the mobility programme) individuals originally from a less developed region. The objective is to understand the location behaviour of individuals that possess unique (observable and unobservable) characteristics that make them particularly valuable to the economy (especially in their region of origin). Our results show that incomes cannot fully explain the location behaviour of FMG, since other important motivations are present: family, social networks, quality of life and so on. In particular, social networks seem to play a crucial role in opening (economic) opportunities in the region of origin that would otherwise remain inaccessible. Moreover, the analysis casts new light on the decision-making process underlying locational choices. Migration is not a linear one-off process as suggested by previous literature. Importantly, it instead looks 
more like a trajectory, which, over time, is likely to lead to brain circulation, which could in turn benefit lagging regions.

\section{Where to go after graduation? Jobs, creative and tolerant places and networks}

Interestingly, given the large amount of funding that has been directed at student mobility, there are only a few studies that explicitly target FMG and these have not arrived at a shared understanding of the determinants of their locational choice following graduation (Geddie 2010; Hazen and Alberts 2006; Marinelli 2011; Venhorst 2013). Even if this field of research is only in its early stages (King and Raghuram 2013; Williams and Baláž 2008), the literature makes it possible to identify a diversified set of potential drivers of the location decisions of FMG. These drivers can be organised around three categories, each covered by distinct (and often conflicting) streams of literature: jobs and economic conditions, 'creative' class environmental factors and social networks, and while this paper is not about migration in general, understanding these models will help us to unpick the reasons why some graduates may wish to return to a lagging region.

In the standard neoclassical economic framework, individuals migrate where they can best maximise their earning potential. These decisions have been viewed through the lens of Human Capital Theory (Sjaastad 1962) and other models of cost-benefit analysis (Borjas 1990) where migration is analogous to any other investment choice: e.g. the monetary and non-monetary rewards of migration are balanced against the maintenance of stasis. In these models, migrants are rational actors seeking the best return on their investment and successful regions are those that can offer the most competitive salaries and employment conditions to potential applicants.

However, a growing body of evidence suggests that large numbers of people are, contrary to the standard model, migrating to areas of low income and high unemployment (Knapp and Gravest 1989). This suggests that utility cannot be reduced to nominal wages but must also incorporate other factors such as cost of livingespecially housing - and available amenities. Concerning the former, high costs of housing and other costs of living reduce real wages. Moreover, amenities play an important role in the migration decision since, depending on their preferences, individuals are willing to forgo part of their earnings in order to have access to amenities such as good climate, green spaces and culture (Glaeser et al. 2001; Graves 1976, 1980, 1983; Roback 1982). In these models, the source of utility is not simply represented by nominal wages but by a mix of different elements including real wages, rents and amenities. In these instances, individuals make locational decisions based on their personal preferences, and as utility equalises across locations, the choice to relocate depends on the evolution of the household's consumption preferences (Knapp and Gravest 1989). The set of factors influencing the location of highly skilled individuals is further extended by advocates of the 'creative class' approach (Florida 2004; Florida et al. 2008): 'what accounts for the ability of some places to secure a greater quantity or quality [of highly skilled inflows] lies in openness, diversity, and tolerance [...] to immigrants, artists, gays, and racial integration. These are the kind of places that, by 
allowing people to be themselves and to validate their distinct identities, mobilize and attract the creative energy' (Florida 2004, p. 7).

However, 'any utility-maximizing calculation must always be subject to feasibility constraints' (Storper and Scott 2009, p. 161): migration can take place only insofar as there are favourable economic conditions and job opportunities in the destination country/region. Of course, individuals endowed with high levels of specialisation and human capital might struggle more to find jobs in their niche, in particular in less developed regions. Therefore, they might be particularly motivated to locate in large (or 'thick') labour markets, endowed with a vast array of specialised jobs (Brown and Scott 2012).

The existing empirical evidence on Europe, despite the tendency of most studies to stress the prevailing importance of economic factors (see for instance Cheshire and Magrini 2006; Faggian and McCann 2009; Ritsilä and Ovaskainen 2001), has recently suggested that quality of life, tolerance and local 'creativity' also play an important role for urban (Faggian and Royuela 2010) and inter-regional (Biagi et al. 2011) European migration. Non-economic factors play a key role also in explaining European migration flows: network effects and regional socio-environmental conditions exert a significant influence over the locational choice of migrants (Rodríguez-Pose and Ketterer 2012).

Beyond the 'economic incentives' versus 'receptiveness of the local environment/tolerance/amenity' debate, scholars are increasingly acknowledging the role of social networks in shaping locational decisions (Haug 2008; Silvey and Lawson 1999). An emerging body of literature (referred to as 'Transnationalism') advocates understanding migration behaviour based on networks, complexity and migration 'stickiness' as opposed to individual rationality, linearity and notions of preset push and pull factors (Basch 1994; Geddie 2010; King 2002; Mosneaga and Winther 2012). While transnationalists do not deny the importance of previous research into migration, they caution against scholarship that does not embed migration within its broader social context (King 2002). Here social networks are broadly defined and encompass a variety of social relations including partnering, parenting, family, friends, business networks and so on. In this sense, social networks include every social tie that has a bearing on individual decisions and actions as transnationalists argue that all of these influence migration trajectories.

The literature on social networks is vast (for a review, see Arango 2000; Massey et al. 1993). However, the strand on Transnationalism is particularly relevant to our work as it stresses that highly skilled migrants keep social and cultural ties not only in the destination country but also back in the sending country (Portes 2000). In this regard, Vertovec contends that 'migration itself can be conceptualized as a process of network building, which depends on and, in turn, reinforces social relationships across space' (2002, p. 3). As such, migration can lead to both migration and return migration. The conceptualisation of the migration decision as a circular process, also referred to as brain circulation (Gaillard and Gaillard 1997), contrasts with the neoclassical approach since migration is no longer considered a one-off decision and also because it is no longer expected to necessarily be negative for the sending country/region. On the contrary, highly skilled international migrants can be of great value for the sending country/region, since their social ties with peers, professionals, family members, friends and so on can result in knowledge flows, foreign direct investment, return 
migration as well as brain circulation (Hazen and Alberts 2006; Meyer 2001; Saxenian 2006; Saxenian et al. 2002; Vertovec 2002). The 'multiple situatedness' of migrants provides them with idiosyncratic structures of constraints and opportunities that shape their professional, economic and location choices (Olwig and Sørensen 2005).

Of course, the study of multinational social and economic networks to explain migratory processes is particularly suitable for students who, after graduation, are called to make important strategic choices related to their careers and personal lives. These decisions can be enabled or constrained by the particular structure and perception of personal ties resulting from individual migratory experience (Geddie 2010). In this scenario, social networks offer insights to why having previous migration experience - as in the case of FMG — can increase the likelihood of future migration (Davanzo 1983; Oosterbeek and Webbink 2011; Salt 1997). For example the recipients of the ERASMUS programme are significantly more likely to be mobile throughout their lives (Guellec and Cervantes 2002; King and Ruiz-Gelices 2003; Parey and Waldinger 2011). In a similar vein, by focusing on the impact of a scheme granting scholarships to students resident in the Italian less developed region of Basilicata, Coniglio and Prota (2008) found that student mobility significantly increases the likelihood of future migration thanks to its impact on the shape and geographical scope of social networks. Similar mechanisms drive return migration, in that having strong social ties in the home country can favour return migration or brain circulation (Hazen and Alberts 2006; Meyer 2001; Saxenian 2006; Saxenian et al. 2002; Vertovec 2002).

In sum, the social network literature drafts a picture in which the migration decision results from the dialectic of opposed networks in the sending and the host country that can open opportunities that otherwise would remain closed and that can lead to migration, return migration or brain circulation. However, most migration scholarship has focused on why locational decisions are made (i.e. what factors determine them), but this work has tended to neglect how the underlying decision-making process occurs. Few studies have analysed the individual narratives of FMG to shed light on how locational decisions are taken in practice. According to King (2012), this interest in the details of migration stories only emerged in the $1990 \mathrm{~s}$, on the wake of the socalled cultural turn (e.g. Barnett 2004; Crang 1997; Thrift 2004) in the social sciences. However, '[this new approach does] not so much re-make theories of the causes of migration as enrich our understanding of the migrant experience' (King 2012, p. 25).

\section{Data and methodology}

\subsection{Data: the Master and Back recipients database}

Traditional studies on return migration have tended to rely on either quantitative or qualitative methods. However, while the former are good at generalising and identifying the relative strengths of different factors in determining the locational decision, the latter can provide a 'thick' description of how the decision-making occurs by drawing from individual experiences and narratives. Given the importance of both aspects, this paper adopts a mixed-method approach-overcoming some of the main weaknesses of either 'pure' method-to the analysis of a unique sample of FMG. 
The empirical analysis looks at the location decisions of the former beneficiaries of 'Master \& Back' (M\&B), a major learning mobility programme launched in 2005 by the Sardinia Region (one of the 'less developed' regions in Europe-see Online Appendix A for some stylised facts on Sardinia and its socio-economic conditions) and co-founded by the European Social Fund (ESF- a financial instrument designed to promote economic development in lagging regions in the European Union) with more than 200 million Euros.

M\&B beneficiaries received a scholarship covering fees and a monthly stipend to pursue postgraduate studies outside Sardinia (either in another Italian region or abroad). The beneficiaries were all residents in the Sardinia Region at the time of application, aged 35 or below and possessed a university degree making them suitable for postgraduate studies with a final grade of 100/110 or above. Virtually all applicants fulfilling these minimum eligibility requirements were actually funded.

Our database includes administrative data on all the recipients of the $M \& B$ Higher Education Programme, from 2006 to 2009 (comprising 1776 records in total) complemented by individual-level information taken from a purpose-designed Web survey with a $44.4 \%$ response rate: overall 788 respondents.

It should be noted that part of the recipients have also received a further grant (socalled Back) from the regional government to lure them back to Sardinia and work there upon completion of their studies. ${ }^{1}$ Insofar as this study is concerned, the 'Back' is a confounding factor since the behaviour of those who received the additional grant might be anomalous when compared to the rest of the sample. More precisely, out of 788 respondents, 291 (37\%) were also granted the 'Back'; of those 170 (22\% of the full sample) were in the 'Back' phase when they were interviewed, while $121(15 \%$ of the full sample) had already concluded it.

In order to minimise potential bias, the 170 observations obtained from individuals surveyed while in the 'Back' phase have been discarded. On the other hand, the 121 observations from those who had already completed this additional programme have been kept in the sample. Thus, the final sample is comprised of all the recipients of the M\&B Higher Education who were not in the 'Back' phase when the survey was conducted. Hereafter we refer to this sample, consisting of 618 valid observations, as the 'standard sample'. As a robustness check, our final specification has been reestimated by excluding all 'Back' recipients (both current and past) in order to exclude any potential bias introduced by this additional programme ('restricted sample').

While the objective of the paper is not an impact evaluation of the M\&B Programme, its recipients form an ideal sample for the study of the location behaviour of FMG.

\footnotetext{
1 For the sake of completeness, it should be highlighted that the 'Master and Back' Programme consists of two completely independent sections/subschemes. The 'Master' section supports either postgraduate studies by regional residents as previously discussed (Higher Education part of the programme), or internships in prestigious Italian or foreign organisations (Internships part of the programme). Our sample exclusively comprises beneficiaries of the Higher Education section of the programme. The 'Back' section provides economic incentives for Sardinian graduates to return to the region after their studies. Involvement in this second section of the programme is not compulsory and completely unrelated (in terms of application, selection procedure, etc.) with the 'Master' section. More information on the characteristics of the programme is available at the following weblink: https://www.regione.sardegna.it/masterandback/. Crescenzi et al. (2015) discuss more in detail some of the technicalities of the programme.
} 
$M \& B$ recipients can be assumed to have similar propensities for geographical mobility, all are endowed with similarly high levels of education, and as the scholarships covered the full cost of education, their social background should be more heterogeneous than one might typically find amongst mobile students (Parey and Waldinger 2011). Some descriptive statistics on the sample of FMG under study are included in Online Appendices B and C. Quantitative data are complemented by 28 in-depth interviews conducted with a sample of programme's beneficiaries.

\subsection{Quantitative methods}

The quantitative analysis is based on a two-step approach. In the first step, the 'income differentials' associated with different location choices are estimated. This makes it possible to quantify the purely monetary incentives associated with different location choices. For this purpose, the following regression is estimated:

$$
\operatorname{INCOME}_{i}=\pi+\beta \text { CURRENTLOCATION }_{i}+\gamma X_{i}+\varepsilon_{i}
$$

where INCOME is net monthly income in euros at $\mathrm{PPP}^{2,3}$ of each former beneficiary of the programme i; CURRENTLOCATION ${ }^{4}$ is the current location of individual $\mathrm{i}$ (back to Sardinia; other Italian Region; Abroad); $\mathrm{X}$ is a vector of standard controls at the individual level (personal: gender, age, field of study at the undergraduate level, level of education; controls for individual ability: final mark 110/110, years beyond normal completion time for undergraduate studies, father's level of education; year of M\&B participation); $\beta$ is the coefficient of interest; and $\varepsilon$ is the error term. The coefficient $\beta$ is informative on the possible (positive or negative) premium associated with the decision to return (or not) to Sardinia.

The second step of the analysis - following the approach of the existing quantitative literature on return migration (see for instance Coniglio and Prota 2008; Li et al. 1996; Soon 2008) - models the drivers of the location decisions of FMG as a function of the key factors identified in the literature: economic and career factors, cultural amenities and tolerance and social networks. The regression model is specified as follows:

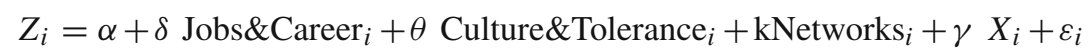

where $\mathrm{Z}=$ odds of return to Sardinia following completion of postgraduate studies outside the region; Jobs\&Career is a vector of proxies for the importance attached by the

\footnotetext{
2 There is some debate in the literature as to whether linear regression or logs of income better describe the data (see, e.g. Grogger and Hanson 2011). We have calculated both, but since both techniques gave similar results, we only report the results for linear regression, whose interpretation is more straightforward

3 In an additional specification, 'Probability of Employment' is tested as an alternative dependent variable, taking value 1 if the individual is currently in employment and 0 otherwise.

4 This is a group of two dummies accounting for the current location of the interviewees: the first takes the value 1 if the interviewee is currently located abroad, and the second takes the value 1 if the interviewee is currently located in an Italian region other than Sardinia. Note that the reference category is Sardinia-i.e. a dummy that takes the value 1 for those currently located in Sardinia.
} 
individuals to career and job-related opportunities and prospects, ${ }^{5}$ Culture $\&$ Tolerance is a vector of proxies for individual preferences for cultural amenities $\&$ an open tolerant environment; Networks is a vector of proxies for the individual embeddedness into social networks both in Sardinia and in the destination region; $X$ is a vector of controls for ability, individual characteristics and other characteristics; $\delta, \theta$ and k are the parameters of interest; and $\varepsilon$ is the error term. A detailed list and description of the variables included in the regression are reported in Online Appendix B.

\subsection{Qualitative methods}

The quantitative analysis shares a number of limitations with other previous similar works (Coniglio and Prota 2008; Güngör and Tansel 2008; Soon 2011, 2010). First, the analysis is purely deductive and is limited to detecting factors that comply with the author's initial expectations, which limits new or novel understandings of the problem. A second weakness lies with the identification of causality links, making it difficult to identify the true drivers of location decisions. Finally, quantitative methods tend to make strong assumptions regarding how the decision-making process unfolds, which can be misleading as they ignore the multiplicity and complexity of economic geographies in which the study's subjects are embedded. To overcome these shortcomings, we performed a further analysis based on qualitative data (Greene et al. 1989; Morgan 2007; Onwuegbuzie and Leech 2005).

In this work, a particular type of mixed-methods approach called 'sequential explanatory design' is used whereby the collection and analysis of quantitative data are followed by the collection and analysis of qualitative data. In this way, the qualitative results are used to further explain and interpret the quantitative ones, thereby providing a richer more nuanced understanding of the data (Creswell 2009; Ivankova et al. 2006). The two phases are then interwoven (Creswell et al. 2003) into two stages: sampling and discussion of the results. This complementary approach enabled us to investigate whether the same push and pull factors tested in the quantitative phase would also emerge inductively. In addition, using sequential explanatory design, we were also able to investigate how FMG perceive opportunities and constraints and how these elements coexist to shape their personal life and migration course. In the end, we were able to better elucidate the nature and also the practice of the decision-making process underlying the location decision.

In-depth interviews were designed to allow the subjects to expand on the narratives around their SM experiences. The interviews focused on their employment both current and in the recent past, on their personal and professional aspirations and on the motivations that underpinned their locational decisions. Interviewees were asked semi-structured questions and were allowed to pursue their responses fully.

The in-depth interviews were based on a purposive sampling approach, which followed these criteria. First, all the interviewees were drawn from the first call of

\footnotetext{
5 These proxies include individual preferences driving location decisions (ease of doing business, availability of good jobs, and availability of good universities and research centres) as well as actual labour market conditions in the destination areas ('local income at PPP' and 'unemployment rate').
} 
the scheme (Call 2006), since they provide scope to assess the recipients' migration choices in the light of a longer time span. Second, the set of interviewees was equally comprised of returners and non-returners; in fact, it was important to explore both the migratory motivations of both those who eventually returned and those who did not. Third, an equal number of females and males were sampled, since migration choice is very gender sensitive. Fourth, only Master's students were considered, since their migration motivations are most likely different from Ph.D. students. Table D-1 in Online Appendix D summarises the sample composition.

\section{Why do they return (or not)? Quantitative results}

Table 1 includes the results of the estimation of the individual income regressions 6 (Eq. 1). Our dependent variable (net monthly income) is regressed on individuals' current location after completion of their studies funded by the M\&B programme and a large set of control variables. Column 1 only looks at the association between current location (i.e. other Italian region and abroad, with Sardinia as the reference category) and some key controls (gender and age at the time of the award of the scholarship). Additional controls for individual characteristics are progressively added in columns 2 to 4 (personal: field of study at the undergraduate level, level of education; controls for individual ability: final mark 110/110, years beyond normal completion time for undergraduate studies, father's level of education; year of M\&B participation). Finally, as a robustness check, column 5 includes the results from a restricted sample that excludes all individuals that received financial incentives to return to Sardinia via the second completely independent leg of the M\&B programme ('Back' programme).

The coefficients of the variables of interest show the expected signs and are robust across specifications. Those individuals who decided to stay abroad earn-ceteris paribus-between 968 to 1019 euros per month more than those who returned to Sardinia. This amount corresponds to roughly $60 \%$ of the average monthly earnings of the full sample, which equals 1618 euros per month. The results also suggest that being located in other Italian regions is not equally advantageous in terms of individual incomes: the net monthly income of individuals located in other Italian regions is not statistically different from that of individuals who decided to return to Sardinia. This is likely to reflect the significant 'compression' of the salary distribution of young graduates in particular at the initial stages of the career in Italy. The key difference between Sardinia and other Italian regions is linked to graduates' employment probability that is higher for both individuals located abroad and in other Italian regions. ${ }^{7}$ The rates of return to Sardinia for individuals who studied abroad versus other Italian regions confirm the intuition of a 'premium' associated with foreign labour markets. Return rates are higher for those who studied in other Italian regions (50\%) than for

\footnotetext{
6 As customary in the literature, only individuals in employment have been considered in this income regression: 396 observations out of the 618 of the standard sample. Qualitatively similar results are obtained when looking at the probability of employment as dependent variable and using the standard sample. These additional results are available upon request.

7 Results on employment probability are not shown but are available upon request.
} 


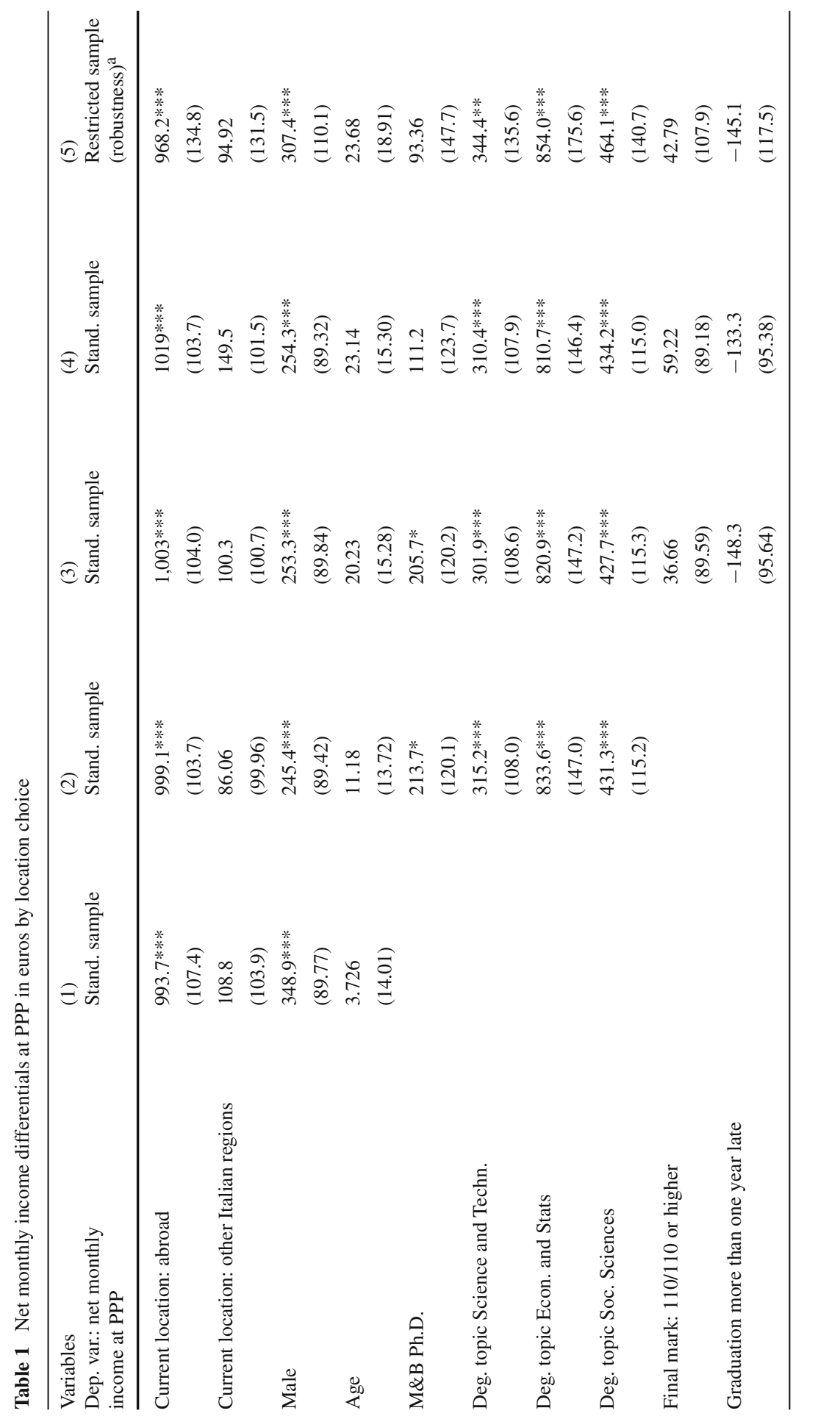




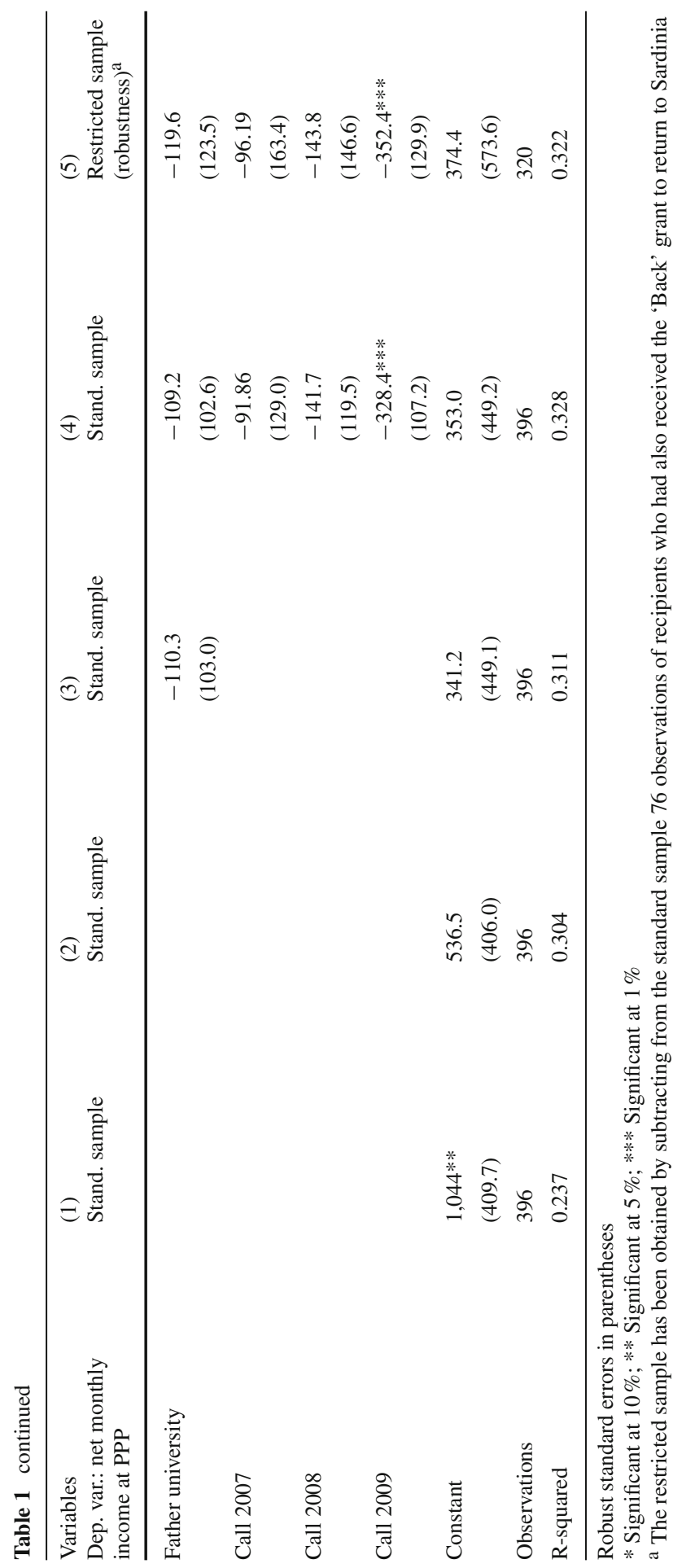


the individuals who went abroad to complete their studies $(36 \%) .{ }^{8}$ Return migration from other Italian regions leads to lower probabilities of employment. However, return from other Italian regions is still higher than from abroad since, on average, going back to Sardinia is economically less penalising when compared to going back from abroad where both employment and income opportunities might be more favourable.

This preliminary evidence suggests that income differentials can explain only part of the return patterns. Therefore, the question that will be addressed next is: besides income, what drives these highly skilled individuals to return (or not to return) to Sardinia?

Table 2 reports the results of the logistic model specified in Eq. 2. The results are reported in odds ratio, which represent the effect of the independent variables on the odds of return to Sardinia occurring. ${ }^{9}$ In columns 1 to 3 , each of the three subsets of independent variables of interest, plus standard controls, has been regressed separately on the outcome of interest: return to Sardinia. In columns 4 and 5 (restricted sample as in Table 1), all the independent variables have been regressed at once in a single model.

The analysis of the career and job-related motivations (column 1) is based on self-reported variables accounting for the importance attached by each interviewee to various career-related factors and objective characteristics of alternative regional/national labour markets. The importance attached by the individuals to the possibility of 'Finding a good job' is negatively associated with return and significant at the $1 \%$ level. Also the importance attached to the possibility to "start own business' is negatively associated with the outcome variable, though more weakly ( $5 \%$ significance). Conversely, the two objective indicators of the economic conditions of the areas of destination- 'local income at PPP' and 'unemployment rate' - are not significantly associated with the probability of return migration. It is the presence of 'good universities and research centres' as a proxy of the innovative capabilities of the host economies that shows a strong and highly significant negative correlation with the probability of return migration. These results confirm the importance of economic and job-related factors in the location choices of mobile individuals. However, they also show that the influence of these factors is highly subjective and hinges more on the perceived constraints and opportunities in alternative locations than on the objective conditions of their labour markets, and thus, not only local opportunities matter but also the access that each individual can have to them. The qualitative analysis will shed additional light on this particular aspect of individual preferences.

In column 2 the proxies for the importance attached to tolerance and cultural amenities are introduced into the model showing negative and highly significant association with return decisions. This suggests that tolerance, cultural and ethnic diversity and

\footnotetext{
8 These data are based on the restricted sample that excludes the individuals who participated into the separate programme to incentivise the return of graduates to Sardinia. For the full sample, the percentage of returners increases significantly, to $39 \%$ for who studied abroad and to $61 \%$ for who studied in another Italian region.

9 It is worth recalling that an odd ratio smaller than 1 should be interpreted as a negative correlation between the independent variable and the dependent variable, while odds ratios higher than 1 should be interpreted as positive correlations (Long 1997).
} 
Table 2 Drivers of return migration: odds ratios from logistic estimation

\begin{tabular}{|c|c|c|c|c|c|}
\hline $\begin{array}{l}\text { Variables } \\
\text { Dep. var.: return } \\
\text { migration }\end{array}$ & $\begin{array}{l}(1) \\
\text { Stand. sample }\end{array}$ & $\begin{array}{l}(2) \\
\text { Stand. sample }\end{array}$ & $\begin{array}{l}\text { (3) } \\
\text { Stand. sample }\end{array}$ & $\begin{array}{l}\text { (4) } \\
\text { Stand. sample }\end{array}$ & $\begin{array}{l}(5) \\
\text { Restricted sample } \\
\text { (robustness) }^{\mathrm{a}}\end{array}$ \\
\hline \multicolumn{6}{|c|}{ Career and job-related motivations } \\
\hline Finding a good job & $\begin{array}{l}0.121 * * * \\
(0.0263)\end{array}$ & & & $\begin{array}{l}0.125 * * * \\
(0.0304)\end{array}$ & $\begin{array}{l}0.145 * * * \\
(0.0413)\end{array}$ \\
\hline Start own business & $\begin{array}{l}0.461 * * \\
(0.155)\end{array}$ & & & $\begin{array}{l}0.405 * * \\
(0.147)\end{array}$ & $\begin{array}{l}0.511 \\
(0.220)\end{array}$ \\
\hline $\begin{array}{l}\text { Unemployment } \\
\text { rate }\end{array}$ & $\begin{array}{l}1.018 \\
(0.0364)\end{array}$ & & & $\begin{array}{l}1.034 \\
(0.0397)\end{array}$ & $\begin{array}{l}1.069 \\
(0.0480)\end{array}$ \\
\hline $\begin{array}{l}\text { Local income at } \\
\text { PPP }\end{array}$ & $\begin{array}{l}0.999 \\
(0.0005)\end{array}$ & & & $\begin{array}{l}1.000 \\
(0.0005)\end{array}$ & $\begin{array}{l}1.000 \\
(0.0005)\end{array}$ \\
\hline $\begin{array}{l}\text { Good universities } \\
\text { research centres }\end{array}$ & $\begin{array}{l}0.0716^{* * * *} \\
(0.0543)\end{array}$ & & & $\begin{array}{l}0.0469 * * * \\
(0.0394)\end{array}$ & $\begin{array}{l}0.0627 * * * \\
(0.0531)\end{array}$ \\
\hline \multicolumn{6}{|c|}{ Cultural amenities \& tolerance } \\
\hline Tolerance & & $\begin{array}{l}0.0905^{* * * *} \\
(0.0564)\end{array}$ & & $\begin{array}{l}0.234 * * \\
(0.167)\end{array}$ & $\begin{array}{l}0.0754 * * \\
(0.0832)\end{array}$ \\
\hline $\begin{array}{l}\text { Cultural/ethnic } \\
\text { diversity }\end{array}$ & & $\begin{array}{l}0.191 * * * \\
(0.111)\end{array}$ & & $\begin{array}{l}0.123 * * * \\
(0.0858)\end{array}$ & $\begin{array}{l}0.121 * * \\
(0.107)\end{array}$ \\
\hline Cultural amenities & & $\begin{array}{l}0.0475 * * * \\
(0.0491)\end{array}$ & & $\begin{array}{l}0.0546 * * * \\
(0.0597)\end{array}$ & $\begin{array}{l}0.0789 * * \\
(0.0880)\end{array}$ \\
\hline \multicolumn{6}{|l|}{ Social networks } \\
\hline Degree in Sardinia & & & $\begin{array}{l}2.476 * * * \\
(0.727)\end{array}$ & $\begin{array}{l}2.243 * * \\
(0.806)\end{array}$ & $\begin{array}{l}2.842 * * \\
(1.242)\end{array}$ \\
\hline ERASMUS & & & $\begin{array}{l}1.076 \\
(0.216)\end{array}$ & $\begin{array}{l}0.998 \\
(0.241)\end{array}$ & $\begin{array}{l}1.034 \\
(0.292)\end{array}$ \\
\hline $\begin{array}{l}\text { Study experience } \\
\text { out }\end{array}$ & & & $\begin{array}{l}1.300 \\
(0.362)\end{array}$ & $\begin{array}{l}1.194 \\
(0.401)\end{array}$ & $\begin{array}{l}1.003 \\
(0.401)\end{array}$ \\
\hline Job experience out & & & $\begin{array}{l}0.386 * * * \\
(0.0803)\end{array}$ & $\begin{array}{l}0.475^{* * * *} \\
(0.118)\end{array}$ & $\begin{array}{l}0.668 \\
(0.196)\end{array}$ \\
\hline $\begin{array}{l}\text { Join no } \\
\text { association }\end{array}$ & & & $\begin{array}{l}1.780 * * * \\
(0.330)\end{array}$ & $\begin{array}{l}2.175 * * * \\
(0.494)\end{array}$ & $\begin{array}{l}2.395^{* * * *} \\
(0.632)\end{array}$ \\
\hline Close to family & & & $\begin{array}{l}2.184 * * * \\
(0.424)\end{array}$ & $\begin{array}{l}0.907 \\
(0.211)\end{array}$ & $\begin{array}{l}1.044 \\
(0.279)\end{array}$ \\
\hline $\begin{array}{l}\text { Married or } \\
\text { unmarried } \\
\text { partner }\end{array}$ & & & $\begin{array}{l}1.351 \\
(0.253)\end{array}$ & $\begin{array}{l}1.310 \\
(0.292)\end{array}$ & $\begin{array}{l}1.310 \\
(0.341)\end{array}$ \\
\hline \multicolumn{6}{|l|}{ Control variables } \\
\hline Male & $\begin{array}{l}1.262 \\
(0.260)\end{array}$ & $\begin{array}{l}1.299 \\
(0.243)\end{array}$ & $\begin{array}{l}1.325 \\
(0.254)\end{array}$ & $\begin{array}{l}1.335 \\
(0.311)\end{array}$ & $\begin{array}{l}1.278 \\
(0.339)\end{array}$ \\
\hline Age treat & $\begin{array}{l}1.062 * \\
(0.0385)\end{array}$ & $\begin{array}{l}1.071 * * \\
(0.0346)\end{array}$ & $\begin{array}{l}1.077 * * \\
(0.0357)\end{array}$ & $\begin{array}{l}1.075^{*} \\
(0.0429)\end{array}$ & $\begin{array}{l}1.102 * * \\
(0.0514)\end{array}$ \\
\hline
\end{tabular}


Table 2 continued

\begin{tabular}{|c|c|c|c|c|c|}
\hline $\begin{array}{l}\text { Variables } \\
\text { Dep. var.: return } \\
\text { migration }\end{array}$ & $\begin{array}{l}\text { (1) } \\
\text { Stand. sample }\end{array}$ & $\begin{array}{l}(2) \\
\text { Stand. sample }\end{array}$ & $\begin{array}{l}\text { (3) } \\
\text { Stand. sample }\end{array}$ & $\begin{array}{l}\text { (4) } \\
\text { Stand. sample }\end{array}$ & $\begin{array}{l}(5) \\
\text { Restricted sample } \\
\text { (robustness) }^{\mathrm{a}}\end{array}$ \\
\hline Higher=Ph.D. & $\begin{array}{l}0.936 \\
(0.260)\end{array}$ & $\begin{array}{l}0.752 \\
(0.186)\end{array}$ & $\begin{array}{l}0.740 \\
(0.189)\end{array}$ & $\begin{array}{l}0.921 \\
(0.297)\end{array}$ & $\begin{array}{l}2.034 * \\
(0.752)\end{array}$ \\
\hline $\begin{array}{l}\text { Deg. topic Science } \\
\text { and Techn. }\end{array}$ & $\begin{array}{l}1.077 \\
(0.261)\end{array}$ & $\begin{array}{l}0.975 \\
(0.215)\end{array}$ & $\begin{array}{l}0.841 \\
(0.194)\end{array}$ & $\begin{array}{l}0.858 \\
(0.234)\end{array}$ & $\begin{array}{l}0.855 \\
(0.277)\end{array}$ \\
\hline $\begin{array}{l}\text { Deg. topic Econ. } \\
\text { and Stats }\end{array}$ & $\begin{array}{l}0.813 \\
(0.289)\end{array}$ & $\begin{array}{l}0.763 \\
(0.245)\end{array}$ & $\begin{array}{l}0.670 \\
(0.221)\end{array}$ & $\begin{array}{l}0.548 \\
(0.217)\end{array}$ & $\begin{array}{l}0.729 \\
(0.328)\end{array}$ \\
\hline $\begin{array}{l}\text { Deg. topic Soc. } \\
\text { Sciences }\end{array}$ & $\begin{array}{l}0.702 \\
(0.195)\end{array}$ & $\begin{array}{l}0.793 \\
(0.204)\end{array}$ & $\begin{array}{l}0.601 * \\
(0.159)\end{array}$ & $\begin{array}{l}0.652 \\
(0.204)\end{array}$ & $\begin{array}{l}0.617 \\
(0.230)\end{array}$ \\
\hline M\&B abroad & $\begin{array}{l}0.537 * \\
(0.192)\end{array}$ & $\begin{array}{l}0.448 * * * \\
(0.102)\end{array}$ & $\begin{array}{l}0.454 * * * \\
(0.108)\end{array}$ & $\begin{array}{l}0.497 * \\
(0.191)\end{array}$ & $\begin{array}{l}0.445^{*} \\
(0.197)\end{array}$ \\
\hline $\begin{array}{l}\text { M\&B in Rome or } \\
\text { Milan }\end{array}$ & $\begin{array}{l}0.715 \\
(0.179)\end{array}$ & $\begin{array}{l}0.617 * * \\
(0.142)\end{array}$ & $\begin{array}{l}0.663 * \\
(0.156)\end{array}$ & $\begin{array}{l}0.657 \\
(0.181)\end{array}$ & $\begin{array}{l}0.598 \\
(0.192)\end{array}$ \\
\hline Father university & $\begin{array}{l}1.097 \\
(0.274)\end{array}$ & $\begin{array}{l}0.850 \\
(0.189)\end{array}$ & $\begin{array}{l}0.736 \\
(0.167)\end{array}$ & $\begin{array}{l}0.945 \\
(0.262)\end{array}$ & $\begin{array}{l}1.031 \\
(0.334)\end{array}$ \\
\hline $\begin{array}{l}\text { Final mark: } \\
\text { 110/110 or } \\
\text { higher }\end{array}$ & $\begin{array}{l}1.175 \\
(0.243)\end{array}$ & $\begin{array}{l}1.299 \\
(0.247)\end{array}$ & $\begin{array}{l}1.105 \\
(0.214)\end{array}$ & $\begin{array}{l}1.046 \\
(0.243)\end{array}$ & $\begin{array}{l}0.940 \\
(0.253)\end{array}$ \\
\hline $\begin{array}{l}\text { Graduation more } \\
\text { than one year } \\
\text { late }\end{array}$ & $\begin{array}{l}0.878 \\
(0.194)\end{array}$ & $\begin{array}{l}0.936 \\
(0.188)\end{array}$ & $\begin{array}{l}0.868 \\
(0.180)\end{array}$ & $\begin{array}{l}0.736 \\
(0.183)\end{array}$ & $\begin{array}{l}0.523 * * \\
(0.155)\end{array}$ \\
\hline Call 2007 & $\begin{array}{l}1.238 \\
(0.381)\end{array}$ & $\begin{array}{l}1.256 \\
(0.352)\end{array}$ & $\begin{array}{l}1.036 \\
(0.287)\end{array}$ & $\begin{array}{l}1.123 \\
(0.384)\end{array}$ & $\begin{array}{l}1.987 * \\
(0.825)\end{array}$ \\
\hline Call 2008 & $\begin{array}{l}0.818 \\
(0.225)\end{array}$ & $\begin{array}{l}0.781 \\
(0.193)\end{array}$ & $\begin{array}{l}0.807 \\
(0.203)\end{array}$ & $\begin{array}{l}1.054 \\
(0.324)\end{array}$ & $\begin{array}{l}2.470 * * \\
(0.932)\end{array}$ \\
\hline Call 2009 & $\begin{array}{l}0.597 * * \\
(0.152)\end{array}$ & $\begin{array}{l}0.610 * * \\
(0.141)\end{array}$ & $\begin{array}{l}0.555^{* *} * \\
(0.132)\end{array}$ & $\begin{array}{l}0.553 * * \\
(0.155)\end{array}$ & $\begin{array}{l}2.312 * * \\
(0.809)\end{array}$ \\
\hline Constant & $\begin{array}{l}1.206 \\
(1.554)\end{array}$ & $\begin{array}{l}0.268 \\
(0.247)\end{array}$ & $\begin{array}{l}0.0714 * * * \\
(0.0719)\end{array}$ & $\begin{array}{l}0.355 \\
(0.512)\end{array}$ & $\begin{array}{l}0.0173 * * \\
(0.0293)\end{array}$ \\
\hline Observations & 618 & 618 & 618 & 618 & 497 \\
\hline Pseudo R-Squared & 0.251 & 0.135 & 0.137 & 0.357 & 0.346 \\
\hline
\end{tabular}

Robust standard errors in parentheses

* Significant at $10 \%$; * Significant at $5 \%$; *** Significant at $1 \%$

a The restricted sample has been obtained by subtracting from the standard sample 121 observations of recipients who had also received the 'Back' grant to return to Sardinia

the presence of 'cultural amenities' are particularly relevant to graduate locational choice. In this regard, the key message is that individuals tend to self-select into return migration depending on the importance they attach to amenities.

In column 3 the proxies for the position of individuals in social networks are assessed. Not surprisingly, the strongest predictor of return migration of this subgroup is 'degree in Sardinia' (positive and significant at $1 \%$ level) with those who 
completed their undergraduate degree in Sardinia more than twice as likely to return. Moreover, having prior (to M\&B) work experience outside Sardinia is negatively and highly significantly associated with return migration. Interestingly and rather counter intuitively, having prior study experiences outside Sardinia does not seem correlated with return. The low incidence of these variables, compared to the previous ones, might be explained by the fact that a job experience outside Sardinia requires a stronger level of adjustment and integration in the host region than does a study experience. The last variable accounting for previous migration experience is 'join no association', which proxies the level of integration in the host region. Not having joined any association or club during their experience outside Sardinia enhances the probability of return by almost twice: low levels of adjustment and integration into local social networks are strong predictors of return and, therefore, confirm previous findings (Baruch et al. 2007). Again, unexpectedly, being 'married or unmarried partner' when the application to $\mathrm{M} \& \mathrm{~B}$ was submitted is not correlated with return migration countering previous literature (Baruch et al. 2007; Güngör and Tansel 2008; Tiemoko 2004). This result is most likely related to the fact that, due to their young average age, few recipients were married or had stable partners when the application was submitted. Finally, the variable 'close to family', is positive and highly statistically significant, a finding also borne out in our qualitative results where respondents were encouraged to be more reflective on their motivations and desires to return. However, in the full models 'close to family' becomes statistically nonsignificant. A potential explanation for this effect is that individuals may be unable to join family despite the desire to do so, perhaps due to exogenous constraints-like the need to find a suitable job. This slightly mismatched finding helps elucidate the importance of considering both qualitative and quantitative findings as a more nuanced story can emerge from the data speaking not just to simple motivations but also longer-term intentions. In summary, column 3 suggests that networks are highly relevant in people's locational choice, particularly having completed their first degree in Sardinia and having family in Sardinia seemed to pull the recipients back to their original location. On the contrary, having work experiences outside Sardinia works as a push factor. However, those who did not form networks within the local environment during their migration experience proved to be more likely to return. This effect may also hinge on the fact that low levels of adjustment in the host country reduce the probability of finding a suitable job there as also some of the interviews in the qualitative section suggest.

In columns 4 and 5 all the subsets of variables considered by the previous models are pulled together in a single framework. The estimates show that the variables, which proxy amenities, are still negatively correlated but tend to loose significance. Individual perceptions of (self-)employment opportunities and innovation continue to be very strong drivers of locational choice, regardless of the sample considered and, as expected, push recipients away from Sardinia. Interestingly, for the network variables, what matters most is the balance between internal Sardinia-based networks and the development of networks in the destination regions/country. If recipients are unable to form adequate networks in the destination region, they tend to return. We also postulate that social networks play a key role in shaping access to job opportunities both in the sending and in the receiving country. In particular, 
social networks may facilitate access to jobs. We explore this further in our qualitative analysis.

\section{How do they decide to return (or not)? Qualitative findings}

\subsection{Drivers of location decisions. Bridging quantitative and qualitative analyses}

In this section, we integrate our quantitative and qualitative results in order to provide a more comprehensive understanding of locational choice. We do this by cross-checking the motivations for return, which were drawn from the literature, in the quantitative stage with motivations freely expressed during interviews with our respondents. Here it is notable that very similar factors emerge: in particular, job opportunities, amenities and social networks.

Moreover, we have further studied the relative influence of different factors and their interplay by putting them into context. On this subject, there is evidence that some motivations are overwhelmingly more important than others-professional motivations and family ties resonate far more strongly with our interviewees than do locational characteristics ${ }^{10}$ and while family ties may not have proved statistically significant in the full model, it was a topic to which our interviewees dedicated a great deal of attention to in our discussions. Moreover, the analysis indicates that social networks play a key role in shaping access to opportunities, both in the sending and in the receiving countries. Our findings challenge the idea that locational decisions are linear and support the notion that choice is partly shaped by prior migration experience, life course (path dependence) and partly by unpredictable interactions with contingent factors (serendipity). Contingent factors are filtered by the individual, who then takes migratory decisions based on his or her perception of opportunities and constraints choosing to locate where they 'feel' better off rather than where objective conditions suggest they would be. This is consistent with the quantitative results, which showed that the perception of constraints and opportunities was more important than the objective economic conditions in alternative locations.

\subsection{Within the black box of decision-making: the individual dynamics of the location decision}

According to the analysis of our in-depth interviews, locational decisions unfold over time and depend on individual perceptions of external opportunities and constraints. Moreover, they are contingent on past migration and on general life experience, which determine how constraints and opportunities are perceived (see, for instance, Geddie 2010). Serendipity has an important influence, since contingent factors interact with individual agency and lead to unexpected or undesired locational outcomes. This complex interplay between different factors makes migration look more like a 'trajectory' than as the linear process supposed by the studies reviewed earlier.

$\overline{10}$ This is consistent with previous literature (Martin-Brelot et al. 2010; Murphy and Redmond 2009). 
To illustrate this, we can take the story of one respondent, a female currently located in Sardinia who provides evidence that many contingent factors can shape the location decision and their interplay can lead to repeat migration. Her account shows that the presence (or the absence) of social networks can significantly affect migration. In addition, we also see that locational decisions are a matter of individual perception of constraints and opportunities, which can vary over time as a function of new information and life experiences. As a matter of fact, I can say that there was no choice in my decision to return to Sardinia because of my contingent situation. I studied in Florence, continued my studies there [Master's] and worked there; I spent 15 years of my life in Tuscany. I was very comfortable, it was like home and I liked everything about Florence: opportunities, multicultural environment [...] and also as far as work was concerned it didn't go too badly. I had my life and I was happy, [I had] friends and business networks. At a certain point of my life, [I made] a series of choices which, if not wrong, were at least untimely. For instance, leaving for a work experience abroad penalized me instead of rewarding me [... $].{ }^{11}$ In short, after a year abroad, she wanted to return to Florence (not to Sardinia), but reintegration in the labour market was very hard since she had partly lost her business networks and since the economic crisis had reduced job opportunities. However, unexpectedly, after six months of unemployment, she was offered a position in Sardinia where she has remained for the last three years. So, despite a sincere desire to return to Florence, she feels bound by work opportunities in Sardinia.

This example is quite peculiar since she is the only interviewee who had never thought of returning to Sardinia after her Master's. However, her account is insightful since it shows that the migration decision is a nonlinear process. Instead, individual agency interacts with contingent factors, which are specific in place and time. The combination of these can lead to completely unexpected or unwanted location outcomes. For instance, in the above case, work experience abroad (generally seen as a career asset) transformed into a constraint due to the economic crisis. Moreover, leaving Italy, if even for a relatively short time, resulted in a substantial loss of her social networks and therefore reduced the opportunities of reintegration. As a result, she found herself caught between a desire to live in her preferred location and an overriding need to work. Interestingly, and something that is neglected in mainstream migration studies, she highlighted the role serendipity played in determining her migration outcome.

The unpredictability of migration trajectories and their dependence on contingent factors also emerges clearly in the story of a male European public relations specialist currently located in Sardinia. He comments that, on completion of my Master's in Rome I did an internship in a theatre [...]. I realised that in Rome there were few

\footnotetext{
11 Original quote in Italian: 'Di sicuro posso dire che la scelta di tornare in Sardegna non è stata per me una vera scelta ma una costrizione dettata da una situazione contingente. Io ho fatto l'università a Firenze, ho proseguito gli studi lì, ci ho lavorato e ci ho passato in totale quasi 15 anni della mia vita [...]. In Toscana mi trovavo benissimo, era diventata casa mia ormai e di Firenze mi piaceva tutto: le opportunità che mi aveva sempre offerto, l'ambiente multiculturale [...] e anche dal punto di vista lavorativo non era andata malaccio. Avevo la mia vita ed ero felice, [avevo] i miei amici ed i miei contatti lavorativi. [... Poi ho] fatto una serie di scelte, se non sbagliate, intempestive, ad un certo punto della mia vita. Ad esempio il fatto di avere svolto un'esperienza all'estero anziché premiarmi mi ha poi penalizzata $[\ldots]$ '.
} 
job opportunities for me. I was in contact with friends in Dublin who convinced me to join them and I spent four very important years there. Afterwards, I kind of got tired of that job and a friend of mine informed me about some job opportunities that were opening in Sardinia. ${ }^{12}$ So, he eventually returned to Sardinia. In this case, as in others, it is clear how migration can be shaped by contingent factors. Additionally, social networks can be seen as vital linkages to work as we see in his trajectory from Rome to Dublin to Sardinia-always on the advice of friends.

Overall, in these and other examples we find evidence of a decision-making process that is influenced by individual preferences, but constrained by objective limitations. Key here is that the balance between preferences (micro-level) and constraints (macrolevel) is mediated by the role played by social networks (meso-level).

\subsection{Brain circulation}

Given our findings on the decision-making process, we wondered whether the resulting migration is a permanent or a temporary phenomenon. As we remarked in the literature review, several scholars have argued that highly skilled migration has become more and more temporary. Often the highly skilled have international careers and experience mobility a number of times: for learning, work or personal reasons. In this regard, the concept of 'brain circulation' has made its way in migration studies, since it is able to depict the circular and temporary nature of modern migration flows (Baláz et al. 2004; Gaillard and Gaillard 1997; Saxenian 2005). Indeed, given our interviewees' responses, there is strong evidence of brain circulation as many of them have experienced mobility several times and are willing to be mobile again. Some of those currently located in Sardinia are willing to migrate again; many of those currently located outside Sardinia wish to return; and finally, several interviewees live peripatetically between countries or regions.

As might be expected, being currently located in Sardinia but wishing to leave again is experienced by people who are unhappy with their employment and therefore want to find an alternative occupation elsewhere. Of course, though the willingness to leave does not necessary result in migration, it makes it much more likely. A male researcher in biology provides us an excellent example. Although he has strong personal ties in Sardinia, he is very critical about the local labour market in his field and is planning to migrate abroad: It is really hard [to make up my mind], but I'd like to find a [job] opportunity abroad [...], I have even thought of [moving to] emerging countries like Brazil. ${ }^{13}$ In short, this interviewee wants to leave since he is unsatisfied with his employment and this motivation seems to be stronger than the presence of family and friends in Sardinia.

\footnotetext{
12 Original quote in Italian: 'Finito il master a Roma ho fatto uno stage in un teatro [...]. Vedevo che a Roma possibilità di lavoro ce n'erano poche, sentivo degli amici a Dublino che mi hanno convinto a salire e ci ho passato quattro anni molto importanti [...]. Dopodiché mi sono un po' stancato di quel lavoro, alla fine non si era aperta la strada e un mio amico mi ha segnalato che si stavano aprendo delle posizioni in Sardegna'.

13 Original quote in Italian: 'E' veramente molto difficile [...] quello che penso ora è di trovare una possibilità all'estero[...], addirittura avevo pensato anche a paesi emergenti tipo il Brasile’.
} 
We also see a cohort of individuals located outside of Sardinia who, through lack of employment, feel forced to migrate yet are bound to the region through strong social and cultural ties. These individuals are ready to return as soon as more favourable professional conditions are found. A female philologist working in Lyon states, I really would have liked to return to Sardinia [on completion of my Master's], but when I realised that there were more opportunities for pursuing a doctorate in France than in Italy, I opted to stay in France. However, I have done a double Ph.D. programme, French-Italian, since my idea was to complete my doctorate in France and then see if any opportunities presented themselves in Sardinia. I still keep an eye on Sardinia, but I haven't seen anything encouraging so far $[\ldots] .{ }^{14}$ Currently, this interviewee works in France, but still wishes to return to Sardinia for personal reasons. It must be stressed that many others interviewees - almost all of them - tried to return on completion of their studies, but, since they could not find a suitable employment, they were forced to extend their migration. Naturally, as time goes by, the likelihood of returning decreases, since adjustment in the host country increases and bonds to the sending region weaken.

Finally we also encountered a number of respondents for whom living across countries had become the norm due to professional and personal ties in both the destination and sending region/country. About $20 \%$ of our interviewees fell into this category as they repeatedly experienced migration between Sardinia and the country where they studied. These stories are significant as they highlight the very contextual and fluid nature of migration.

In our first example, a male engineer who studied in Spain returned briefly to Sardinia to take the state examination to become a professional engineer and then left again to Barcelona where the economic conditions were good at that time and where he started a long collaboration with an engineering firm. Nevertheless, he also kept strong social ties in Sardinia since his family was there and since he hoped to open his own engineering firm exploiting his social networks in Sardinia. During the peak of the economic crisis, he returned to Sardinia for a couple of years and then left again for Barcelona. Currently, he works both in Sardinia and in Spain. His family is in Sardinia, his girlfriend lives in Barcelona and he is happy living in both. As he states: I believe that in my profession keeping in touch with different societies is important [...]. I do not see why I should only work in Sardinia when the most important design firms work in various continents. ${ }^{15}$

Another example can be found in male architect also located in Barcelona and Sardinia. Upon completion of his Master's in Barcelona, he tried to 'keep his feet on both sides'. He wanted to return to Sardinia since that is where his family was, and

\footnotetext{
14 Original quote in Italian: A me sarebbe molto piaciuto tornare in Sardegna [alla fine del mio master] ma quando ho visto che qui era molto più semplice entrare in un dottorato su un progetto che a Cagliari o si entrava con borsa o molto difficilmente si sarebbe entrati ho optato per la Francia ma considera che io ho avuto la co-tutela proprio per mantenere un piede anche in Sardegna, quindi io ho fatto un doppio dottorato franco-italiano per cui l'idea era di fare il dottorato in Francia e poi vedere che possibilità si potevano aprire in Sardegna, per cui l'occhio ce l'ho sempre puntato anche se non vedo nulla di incoraggiante.

15 Original quote in Italian: 'Credo che assolutamente nella mia professione sia sempre fondamentale restare in contatto con altre realtà $[\ldots]$ non vedo perché dovrei lavorare solo per la Sardegna visto che i più grandi studi di progettazione lavorano per i vari continenti'.
} 
he also wanted to start his own business there. At the same time, he was attracted by professional opportunities in the more challenging and creative environment of Barcelona. Currently he is professionally tied to both Sardinia and Barcelona and in the future, he says, 'with some friends [we are] trying to open a [design] studio in Barcelona comprised of people of various nationalities, which gives us contacts in each of our respective countries'. ${ }^{16}$

A final example is provided by a male social scientist, who upon completion of his $M \& B$ experience in the Netherlands returned to Sardinia where he felt most at home. Despite his return, his current work activity requires frequent contacts with professional collaborators outside Sardinia. He currently works for the University for Cagliari as a researcher, which brings him into daily communication with colleagues outside of Sardinia. He also collaborates with his brother, who is partner in a firm specialised in solar panel installations. To perform this work, he needs to constantly coordinate his activities with another partner of the firm who is German and lives abroad. When asked about the reason why he values so much exchanging ideas with contacts outside Sardinia, his reply was: [Being connected with people outside Sardinia is important since] it makes it easier to access ideas at the professional and personal levels. It is important to be close to the technological frontier, so every place where there ideas circulate enriches us both professionally and personally. Whatever your job is, you can improve it if you work with others and if these others belong to your broader social networks. ${ }^{17}$

In summary, all of these examples provide evidence of brain circulation. For personal and professional reasons, the lives of these interviewees are currently articulated in multiple geographical locations. There is evidence that having good social networks in multiple countries is a key condition for the occurrence of brain circulation. In fact, social networks provide access to job opportunities that would not otherwise be accessible. To conclude, these examples of brain circulation challenge the idea of migration as a one-off decision and open up new possibilities, in particular for lagging regions, to reap the returns to their investment in human capital, even if proper return migration does not take place. In fact, various studies have provided evidence that highly skilled individuals coming from lagging regions could benefit their sending regions, even if they do not return, through the generation of inward knowledge flows and FDI (see for instance Baláz et al. 2004; Le 2008; Saxenian 2006).

\section{Conclusions}

Individuals currently located abroad tend to gain - in terms of personal incomesignificantly more than those who have returned to Sardinia. In contrast, being located

\footnotetext{
16 Original quote in Italian: 'fare qualcosa sia qui che lì. Ad esempio con alcuni amici stiamo tentando di aprire uno studio avendo base a Barcellona, ma essendo formato da persone con diverse nazionalità potrebbe avere contatti con i diversi paesi di ognuno'.

17 Original quote in Italian: 'E' più facile avere accesso alle idee sia a livello professionale che a livello umano [...]. E' importante infatti stare vicini alla frontiera tecnologica ovvero qualunque luogo ove ci sia circolazione di idee a qualunque livello arricchisca personalmente e professionalmente. [...] qualunque lavoro fai migliori se lavori con altri e se questi altri fanno parte di una rete più ampia'.
} 
in other Italian regions only impacts probabilities of employment but-for those in employment-remains almost irrelevant from a real salary viewpoint. This could explain why, on average, students who pursued their Master's or Ph.D. abroad are less likely to return than those who completed their studies in other Italian regions. Nevertheless, this effect does not explain why many of those who were located abroad did return and why many of those located in other Italian regions did not.

In this respect, economic factors are not the only drivers of highly skilled migration. Career/professional motivations, cultural amenities and tolerance and social networks are all relevant in explaining return decisions. Lack of individual access to economic opportunities (jobs and business creation) as well as good universities and research centres is a key factor keeping graduates away from Sardinia. Individuals that attach a significant importance to ethnic diversity and cultural amenities are also significantly less likely to return to Sardinia. However, while family considerations do not play a central role, the degree to which individuals are embedded into social networks is key. Previous job experience outside Sardinia (with the corresponding establishment of social and professional connections) reduces the probability of return. Conversely, if individuals fail to establish connections while outside their region (i.e. during their graduate studies), they are more likely_ceteris paribus - to return. Symmetrically, pre-existing networks in Sardinia also increase return migration. As a consequence, social networks seem to play a very relevant role as factors balancing push and pull migration factors.

Concerning the personal dynamics of migration as they emerge from the narratives of the interviewees, we found evidence that some factors are overwhelmingly more important than others. In particular, professional reasons are by far the most important non-return motivation, while family and sentimental ties are the most important return motivations. In contrast, amenities were less significant than expected: very few interviewees mentioned such motivations and, when they did, never as key drivers. Interviewees are in a stage of their lives - they have entered recently the labour market-where finding (suitable) employment and progressing in their careers is by far their most important goal.

Social networks provide another interesting finding. It emerges that social networks are particularly important to access labour opportunities. In fact, many recipients returned to Sardinia because they expected their social networks there to be a fundamental source of support both in finding a job and in starting a new business. On the other hand, for many of the non-returners, having established good social networks in the destination country proved to be extremely important to finding employment there.

With regard to the nature of the decision-making process, consistent with Transnationalism literature, our findings show that human agency is constrained or enabled by the individual perception of contingent factors. Location choice usually depends on prior migration experience and life experience, which affect individual perceptions of migration constraints and opportunities. As such, migration behaviour should always be contextualised in time and space.

In our analysis, we also found strong evidence of brain circulation, which disproves the idea of migration as a one-off decision: various interviewees who have already returned to Sardinia are willing to migrate again and others, currently located outside 
Sardinia, wish to return. Moreover, we find evidence that various interviewees are currently living across countries and wish to continue living this way for professional and personal reasons. There is also evidence that the circularity of migration behaviour is related to the role played by social networks in creating (job) opportunities in different locations.

These findings allow us to draw some lessons that can be useful for policy makers investing in SM in lagging regions. Our analysis provides evidence that economic considerations are not the only important factor shaping the location decisions of highly skilled formerly mobile graduates, since individuals can be influenced differently by different factors. In this regard, it is the individual access to opportunities that matters, suggesting that more open and meritocratic local labour markets are keys to foster brain gain. Alternative levers should also be tested, for example, by reinforcing the participation of mobile students and migrants into local associations linked to cultural activities but also to universities (Alumni associations) or professional bodies in order to reinforce their embededness into social and professional networks. Moreover, since migration is a process which evolves over time, for the same individual different factors might be successful at different stages of life.

Another key policy implication of this work is that closer attention should be paid to brain circulation. In fact, triggering return migration might not be the only way to reap the returns from the regional investment in human capital. For instance, the creation of job opportunities that allow teleworking or flexible location should be favoured and supported. Moreover, opportunities for networking between Sardinian firms and highly skilled migrants should be supported in order to favour inward knowledge flows towards Sardinia. This strategy in policy making is usually referred to as 'diaspora option' (Thorn and Holm-nielsen 2008). Policy makers should accept the idea of brain circulation maximising individuals' flexibility in locational choice and favouring emerging inter-regional and transnational career arrangements that might increase both individual (by preserving social networks and emotional connections) and territorial (by maximising knowledge exchange and economic opportunities) wealth.

Open Access This article is distributed under the terms of the Creative Commons Attribution 4.0 International License (http://creativecommons.org/licenses/by/4.0/), which permits unrestricted use, distribution, and reproduction in any medium, provided you give appropriate credit to the original author(s) and the source, provide a link to the Creative Commons license, and indicate if changes were made.

\section{References}

Arango J (2000) Explaining migration: a critical view. Int Social Sci J 52(165):283-296

Baláz V, Williams AM, Kollár D (2004) Temporary versus permanent youth brain drain: economic implications. Int Migr 42(4):3-34

Barnett C (2004) A critique of the cultural turn. In: Duncab S, Nuala NC, Johnson C, Schein RH (eds) A companion to cultural geography. Blackwell, Oxford

Baruch Y, Budhwar PS, Khatri N (2007) Brain drain: inclination to stay abroad after studies. J World Bus 42(1):99-112

Basch LG (1994) Nations unbound: transnational projects, postcolonial predicaments, and deterritorialized nation-states. Gordon and Breach, London 
Biagi B, Faggian A, McCann P (2011) Long and short distance migration in Italy: the role of economic, social and environmental characteristics. Spat Econ Anal 6(1):111-131

Borjas GJ (1990) Friends or strangers: the impact of immigrants on the US economy. Basic Books, New York

Brown WM, Scott DM (2012) Human capital location choice: accounting for amenities and thick labor markets. J Reg Sci 52(5):787-808

Cheshire PC, Magrini S (2006) Population growth in European cities: weather matters-but only nationally. Reg Stud 40(1):23-37

Coniglio ND, Prota F (2008) Human capital accumulation and migration in a peripheral EU region: the case of Basilicata*. Pap Reg Sci 87(1):77-95

Crang M (1997) Cultural geography. Routledge, London

Crescenzi R, Gagliardi L, Orru' E (2015) Learning mobility grants and skill (mis)matching in the labour market. The case of the 'Master and Back' Programme. Pap Reg Sci. doi:10.1111/pirs.12155

Creswell JW (2009) Research design: qualitative, quantitative, and mixed methods approaches. Sage Publications, Thousand Oaks

Creswell JW, Plano clark VL, Gutmann ML, Hanson WE (2003) Advanced mixed methods research designs. In: Tashakkori A, Teddlie C (eds) Handbook of mixed methods in social and behavioral research. Sage, Thousand Oaks

Davanzo J (1983) Repeat migration in the United States: Who moves back and who moves on? Rev Econ Stat 65(4):552-559

European Commission (2002) Action plan for skills and mobility. EC, Brussels, Belgium

European Commission (2012) Study on mobility developments in school education, Vocational Education and Training. Adult Education and Youth Exchanges, Brussels

Faggian A, McCann P (2009) Human capital, graduate migration and innovation in British regions. Camb J Econ 33(2):317

Faggian A, Royuela V (2010) Migration flows and quality of life in a Metropolitan Area: the case of Barcelona-Spain. Appl Res Qual Life 5(3):241-259

Florida R (2004) Cities and the creative class. Routledge, New York

Florida R, Mellander C, Stolarick K (2008) Inside the black box of regional development-human capital, the creative class and tolerance. J Econ Geography 8(5):615-649

Gaillard J, Gaillard AM (1997) Introduction: The international mobility of brains: exodus or circulation? Sci Technol Soc 2(2):195-228

Geddie KP (2010) Transnational landscapes of opportunity? Ph.D. thesis, University of Toronto

Glaeser EL, Kolko J, Saiz A (2001) Consumer city. J Econ Geography 1(1):27-50

Graves PE (1976) A reexamination of migration, economic opportunity and quality of life. J Reg Sci 16(1):107-112

Graves PE (1980) Migration and climate. J Reg Sci 20(2):227-237

Graves PE (1983) Migration with a composite amenity: the role of rents. J Reg Sci 23(4):541-546

Greene JC, Caracelli VJ, Graham WF (1989) Toward a conceptual framework for mixed-method evaluation designs. Educ Eval Policy Anal 11(3):255-274

Guellec D, Cervantes M (2002) International mobility of highly skilled workers: from statistical analysis to policy formulation. In: OECD (ed) International mobility of the highly skilled. OECD Publications, Paris

Güngör ND, Tansel A (2008) Brain drain from Turkey: an investigation of students' return intentions. Appl Econ 40(23):3069-3087

Haug S (2008) Migration networks and migration decision-making. J Ethn Migrat Stud 34(4):585-605

Hazen HD, Alberts HC (2006) Visitors or immigrants? International students in the United States. Popul Space Place 12(3):201-216

Ivankova NV, Creswell JW, Stick SL (2006) Using mixed-methods sequential explanatory design: from theory to practice. Field Methods 18(1):3-20

King R (2002) Towards a new map of European migration. Int J Popul Geogr 8(2):89-106

King R (2012) Geography and migration studies: retrospect and prospect. Popul Space Place 18(2):134-153

King R, Raghuram P (2013) International student migration: mapping the field and new research agendas. Popul Space Place 19(2):127-137

King R, Ruiz-Gelices E (2003) International student migration and the European 'Year Abroad': effects on European identity and subsequent migration behaviour. Int J Popul Geogr 9(3):229-252 
Knapp TA, Gravest PE (1989) On the role of amenities in models of migration and regional development. J Reg Sci 29(1):71-87

Le T (2008) 'Brain Drain'or 'Brain Circulation': evidence from OECDs international migration and R\&D spillovers. Scott J Poli Econ 55(5):618-636

Li FLN, Findlay AM, Jowett AJ, Skeldon R (1996) Migrating to learn and learning to migrate: a study of the experiences and intentions of international student migrants. Int J Popul Geogr 2(1):51-67

Long JS (1997) Regression models for categorical and limited dependent variables. Sage, London

Marinelli E (2011) Graduate migration in Italy-Lifestyle or necessity?. ERSA conference papers

Martin-Brelot H, Grossetti M, Eckert D, Gritsai O, Kovács Z (2010) The spatial mobility of the "creative class': a European perspective. Int J Urban Reg Res 34(4):854-870

Massey DS, Arango J, Hugo G, Kouaouci A, Pellegrino A, Taylor JE (1993) Theories of international migration: a review and appraisal. Popul Dev Rev 19(3):431-466

Meyer J (2001) Network approach versus brain drain: lessons from the diaspora. Int Migrat 39(5):91-110

Milio S, Lattanzi R, Casadio F, Crosta N, Raviglione M, Ricci P, Scano F (2012) Brain drain, brain exchange and brain circulation. The case of Italy viewed from a global perspective. National interest. Aspen Institute Italia, Milan

Morgan DL (2007) Paradigms lost and pragmatism regained methodological implications of combining qualitative and quantitative methods. J Mixed Methods Res 1(1):48-76

Mosneaga A, Winther L (2012) Emerging talents? International students before and after their career start in Denmark. Popul Space Place 19(2):181-195

Murphy E, Redmond D (2009) The role of 'hard'and 'soft' factors for accommodating creative knowledge: insights from Dublin's ‘creative class'. Irish Geogr 42(1):69-84

Olwig KF, Sørensen NN (2005) Mobile livelihoods. In: Sørensen NN, Olwig KF (eds) Workand migration: life and livelihoods in a globalizing world. Routledge, New York

Onwuegbuzie AJ, Leech NL (2005) On becoming a pragmatic researcher: the importance of combining quantitative and qualitative research methodologies. Int J Social Res Methodol 8(5):375-387

Oosterbeek H, Webbink D (2011) Does studying abroad induce a brain drain? Economica 78(310):347-366

Parey M, Waldinger F (2011) Studying abroad and the effect on international labour market mobility: evidence from the introduction of erasmus. Econ J 121(551):194-222

Portes A (2000) Globalization from below: the rise of transnational communities. Ends Glob Bring Society Back 253-270

Ritsilä J, Ovaskainen M (2001) Migration and regional centralization of human capital. Appl Econ $33(3): 317-325$

Roback J (1982) Wages, rents, and the quality of life. J Polit Econ 90(6):1257-1278

Rodríguez-Pose A, Ketterer TD (2012) Do local amenities affect the appeal of regions in Europe for migrants? J Reg Sci 52(4):535-561

Salt J (1997) International movements of the highly skilled. OECD Publishing, Paris

Saxenian A (2005) From brain drain to brain circulation: transnational communities and regional upgrading in India and China. Stud Comp Int Dev 40(2):35-61

Saxenian A (2006) The new argonauts: regional advantage in a global economy. Harvard University Press, Cambridge

Saxenian A, Motoyama Y, Quan X (2002) Local and global networks of immigrant professionals in Silicon Valley. Public Policy Inst of California

Silvey R, Lawson V (1999) Placing the migrant. Ann Assoc Am Geogr 89(1):121-132

Sjaastad LA (1962) The costs and returns of human migration. J Polit Econ 70(5):80-93

Soon J-J (2011) Home is where the heart is? Factors determining international students' destination country upon completion of studies abroad. J Ethn Migrat Stud 38(1):147-162

Soon JJ (2008). The determinants of international students' return intention. Working Papers. Otago, New Zeland, University of Otago, Department of Economics

Soon JJ (2010) The determinants of students' return intentions: a partial proportional odds model. J Choice Modell 3(2):89-112

Storper M, Scott A (2009) Rethinking human capital, creativity and urban growth. J Econ Geogr 9(2):147

Thorn K, Holm-nielsen LB (2008) International mobility of researchers and scientists: Policy options for turning a drain into a gain. In: Solimano A (ed) The international mobility of talent: types, causes, and development impact. Oxford University Press, New York

Thrift N (2004) Knowing capitalism. Sage, London 
Tiemoko R (2004) Migration, return and socio-economic change in West Africa: the role of family. Popul Space Place 10(2):155-174

Venhorst VA (2013) Graduate migration and regional familiarity. Tijdschrift Voor Economische En Sociale Geografie 104(1):109-119

Vertovec S (2002) Transnational networks and skilled labour migration. University of Oxford, Transnational Communities Programme

Williams AM, Baláž V (2008) International migration and knowledge. Routledge, Abingdon 